\title{
Sosialisasi Penggunaan Tanaman Obat dalam Meningkatkan Sistim Imun Tubuh Dimasa Pandemi Covid-19
}

\author{
Muharni $^{1 *}$, Fitrya $^{2}$, Heni Yohandini ${ }^{1}$, Maryadi $^{3}$ \\ ${ }^{I}$ Jurusan Kimia, Fakultas Matematika dan Ilmu Pengetahuan Alam, Universitas Sriwijaya, Indralaya, \\ Sumatera Selatan, Indonesia \\ ${ }^{2}$ Jurusan Kimia, Fakultas Matematika dan Ilmu Pengetahuan Alam, Universitas Sriwijaya, Indralaya, \\ Sumatera Selatan Indonesia \\ ${ }^{3}$ Program Studi Agribisnis, Fakultas Pertanian. Universitas Sriwijaya, Sumatera Selatan, Indonesia
}

\author{
Article history \\ Received: 27 Mei 2021 \\ Revised: 11 Juni 2021 \\ Accepted: 23 Juni 2021 \\ *Corresponding Author: \\ Muharni, Fakultas \\ Matematika dan Ilmu \\ Pengetahuan Alam, \\ Universitas Sriwijaya, \\ Indralaya, \\ Sumatera Selatan, Indonesia \\ Email: \\ sutariati69@yahoo.co.id
}

Abstract: In 2020, world was experiencing a health crisis known as the COVID-19 pandemic. The government has taken a policy to urge people to do three things, namely using masks, maintaining distance, and washing hands frequently. But the most important thing is to maintain the body's own immune system. This disease is very easy to contract in people with weak immune systems. Several traditional medicinal plants have been reported to be used to boost the immune system. The level of public education is still low, especially in RT 7 LK IV Indralaya Mulya, then it is necessary to provide education in improving the body's immune system. The purpose of this activity was to educate the public about the immune system and introduce medicinal plants that can improve the body's immune system. This activity was carried out using lecture and survey methods. The survey results shows that $<50 \%$ of people do not understand the dangers of COVID-19, people were less concerned about protecting themselves so that there was no effort to improve the immune system. People also do not understand that medicinal plants such as turmeric and ginger could be consumed to boost the immune system. With the implementation of this counseling activity, the community began to understand the dangers of COVID-19 and have awareness of protecting themselves by increasing the body's immune system through the consumption of various medicinal plants. This activity also helps the government in controlling the spread of COVID-19.

Keywords: ginger; immature; medical; turmeric; system

Abstrak: Sejak tahun 2020 hampir seluruh dunia mengalami krisis kesehatan yang dikenal dengan pandemi COVID-19. Pemerintah telah mengambil kebijakan menghimbau masyarakat untuk menjalankan tiga hal yaitu menggunakan masker, menjaga jarak, dan sering mencuci tangan. Namun hal terpenting adalah menjaga sistim imun tubuh sendiri. Penyakit ini sangat mudah terjangkit pada orang dengan sistim imun yang lemah. Beberapa tanaman obat tradisional telah dilaporkan dapat meningkatkan sistim imun. Masih rendahnya tingkat pendidikan masyarakat khususnya di RT 7 LK IV Indralaya Mulya, maka perlu diberikan edukasi dalam meningkatkan sistim imun tubuh. Tujuan kegiatan ini adalah memberikan edukasi kepada masyarakat tentang sistim imun dan memperkenalkan tumbuhan obat yang mampu meningkatkan sistim imun tubuh. Kegiatan dilaksanakan dengan metode ceramah dan survey. Hasil survey menunjukkan bahwa $<50 \%$ masyarakat kurang paham tentang bahaya COVID-19 dan masyarakat kurang peduli dalam melindungi dirinya sehingga tidak ada usaha untuk meningkatkan sistim imun. Masyarakat juga tidak paham bahwa tumbuhan obat seperti kunyit, jahe, temu lawak, meniran, dan pegagan dapat dikonsumsi untuk meningkatkan sistim imun. Dengan terlaksanakannya kegiatan penyuluhan ini masyarakat mulai paham bahaya COVID-19 dan timbul kesadaran melindungi diri dengan cara meningkatkan sistim imun tubuh melalui konsumsi berbagai tumbuhan obat. Kegiatan ini juga membantu pemerintah dalam pengendalian penyebaran COVID-19.

Kata kunci: jahe; muda; medis; kunyit; sistem 


\section{PENDAHULUAN}

Saat ini Indonesia dan bahkan hampir seluruh negara di dunia mengalami pandemi yang dikenal dengan nama COVID-19. Penyakit ini dapat menyerang seluruh kalangan dan sangat mudah menular. Pemerintah sudah mengambil kebijakan mengimbau kepada masyarakat untuk menggalakkan gerakan 3M yaitu menggunakan masker, menjaga jarak, dan sering mencuci tangan. Disamping itu masyarakat juga dihimbau untuk meningkatkan sistim imun tubuh agar terhindar dari penyakit ini. Sistem daya tahan tubuh atau imunitas secara sederhana dapat dipahami sebagai sistem kerja tubuh untuk melawan penyakit. Sistem ini akan melindungi tubuh dari serangan organisme atau kuman yang dapat menyebabkan penyakit (Adhi, 2020). Untuk itu setiap orang juga dihimbau untuk meningkatkan sistim imun diri masing-masing. Peningkatan sistim imun dapat dilakukan dengan berbagai cara salah satunya adalah dengan mengkosumsi tumbuhan obat yang dapat meningkatkan sistim imun.

Salah satu daerah yang cukup dekat dengan kampus Universitas Sriwijaya adalah RT 7 LK IV Kelurahan Indralaya Mulya. Kelurahan ini berjarak \pm 4 KM dari kampus Universitas Sriwijaya di Indralaya. Masyarakatnya berasal dari berbagai daerah dengan mayoritas merupakan warga transmigrasi dari daerah Jawa, dengan tingkat pendidikan yang rata-rata tamat SD dan SMP. Warga umumnya masih belum memahami akan pentingnya arti pendidikan bagi generasi penerus, sehingga anak-anak di sini cendrung putus sekolah sampai SMP. Hal ini juga berkaitan dengan tingkat pendapatan warga yang relatif tidak mampu, dimana untuk pemenuhan kebutuhan seharihari saja warga RT ini cendrung susah. Mata pencaharian warga umumnya bertani, berkebun, dan sebagai buruh harian seperti buruh cuci, tenaga kebersihan dan lain-lain. Keadaan perekonomiannya masih rendah. Kondisi ini menyebabkan masyarakat sulit memenuhi kebutuhan hidupnya apalagi biaya berobat yang sangat mahal menyebabkan masyarakat khususnya warga RT 7 LK IV kelurahan Indralaya Mulya kecamatan indralaya menggunakan bahan-bahan obat tradisional untuk menjaga kesehatannya (Hikayati, 2014). Di kelurahan Indralaya mulya juga telah dilaporkan kegiatan pengabdian Penatalaksanaan non farmakologis terapi komplementer sebagai upaya untuk mengatasi dan mencegah komplikasi sebagai upaya untuk mengatasi dan mencegah komplikasi pada penderita hipertensi primer di kelurahan indralaya mulya kabupaten Ogan Ilir (Hikayati, 2014). Selanjutnya Flora, dkk., (2013), telah melakukan kegiatan pengabdian Pelatihan senan kaki pada penderita Diabetes mellitus dalam upaya pencegahan komplikasi diabetes pada kaki (diabetes food).

Pada situasi saat ini dengan adanya pamdemi COVID-19 masyarakat lebih dituntut untuk menjaga kesehatannya. Salah satunya adalah meningkatkan sistim imun. Beberapa tanaman obat tradisional telah dilaporkan dapat digunakan untuk meningkatkan sistim imun tubuh. Terdapat sejumlah tanaman obat yang baik dikonsumsi untuk meningkatkan daya tahan tubuh, terlebih pada masa pandemi COVID-19 sekarang ini diantaranya kunyit (Curcuma domestica), jahe (Zingiber officinale), temu lawak (Curcuma xanthorhiza), meniran (Phylanthus niruri), mengkudu (Morinda citrifolia), pegagan (Cantela asiatica) dan lain-lain. Tumbuhan ini sangat mudah ditemukan dilingkungan kita. Mengingat penyakit atau wabah COVID-19 sampai saat ini masih belum terkendali, maka masyarakat khususnya warga Kelurahan Indralaya mulya Kecamatan Indralaya dengan rata-rata pendidikan yang rendah perlu diberkan edukasi tentang tanaman obat yang dapat digunakan untuk meningkatkan 
sistim imun tubuh dimasa pandemi COVID-19. Keberhasilan kegiatan ini dapat membantu masyarakat terhindar dari wabah penyakit ini dan juga membantu pemerintah secara tidak langsung dalam mengendalikan wabah ini.

\section{METODE}

\section{Waktu dan Tempat Kegiatan}

Kegiatan ini telah dilaksanakan pada November 2020 di RT7 LK IV Kelurahan Indralaya mulya Kecamatan Indralaya Utara Ogan Ilir Sumatera Selatan. Khalayak sasaran dalam kegiatan ini adalah ibu-ibu warga RT7 LK IV Indralaya Mulya.

\section{Metode Pelaksanaan Kegiatan Pengabdian}

Metode kegiatan yang akan dilakukan adalah survey, sosialisasi dan peragaan. Pada awal kegiatan dilakukan survey tentang pengetahuan masyarakat tentang penyakit COVID-19, sistim imun, dan tumbuhan obat tradisional. Survey menggunakan kuisioner tentang pengetahuan masyarakat tentang Covid-19, sistim imun dan jenis-jenis tumbuhan obat tradisional manfaat dan kegunaannya. Survey menggunakan 20 orang responden yang akan memberikan penilaian dengan skor $1=$ sangat tidak paham; $2=$ tidak paham; $3=$ Cukup paham; $4=$ Paham; dan 5 = sangat paham.

Selanjutnya dilakukan sosialisasi tentang sistim imun, penyakit COVID-19 dan penjelasan tentang tanaman obat yang dapat digunakan untuk meningkatkan sistim imun tubuh. Sosialisasi disampaikan dengan ceramah dan diskusi dengan masyarakat. Untuk mengetahui tingkat pemahaman dan keingintahuan masyarakat tentang sistim imun dan tanaman obat yang digunakan untuk meningkatkan sistim imun, maka diadakan forum diskusi antara tim dengan khalayak sasaran.

\section{HASIL DAN PEMBAHASAN}

Kegiatan pengabdian pada masyarakat dengan tema Sosialisasi Penggunaan Tanaman Obat Dalam Meningkatkan Sistim Imun Tubuh Dimasa Pandemi COVID-19 telah dilaksanakan di RT 7 LK IV Kelurahan Indralaya Mulya Kecamatan Indralaya Sumatera Selatan pada hari Senin 16 November 2020. Berhubung dalam suasana pandemi ini, maka peserta kegiatan dibatasi jumlahnya. Kegiatan ini diikuti oleh ibu-ibu sebanyak 25 orang dan dihadiri oleh ketua RT. Pada awal pelaksanaan kegiatan untuk melihat sejauh mana pengetahuan masyarakat maka dilakukan pengisian kuesioner yang berkaitan dengan pandemi COVID-19, sistim imun, dan tumbuhan obat tradisional yang dapat digunakan untuk meningkatkan sistim imun. Hasil pengisian kuisioner ditunjukkan pada Tabel 1-3. 
Tabel 1.

Pemahaman responden tentang COVID-19



Survey dilakukan terhadap 20 orang responden. Berdasarkan data Tabel 1 terlihat tingkat pemahaman masyarakat tentang kovid 19 masih sangat rendah. Dari total 7 pertanyaan yang di lontarkan berkaitan tentang covid -19 hanya satu poin yang mendapatkan skor diatas 50\% yaitu apakah paham tentang covid-19 dengan nilai skor 3 (cukup paham). Namun pada pertanyaan lain yang berkaitan dengan covid tentag bahayanya, gejala, penyebaran, usaha melindungi diri didapatkan nilai dibawah 50\% dengan skor 3 (cukup paham). Selanjutnya dilakukan penghitungan total skor untuk masalah tentang covid. Pada Tabel 1terlihat nilai tertinggi 42,1\% dengan skor 3 (cukup paham). Berdasarkan data ini terlihat tingkat kepedulian dan pengetahuan masyarakat tentang Covid19 ini sangat rendah.

Untuk hal yang berkaitan dengan sistim imun hasil survey ditunjukkan pada Tabel 2. Data pada Tabel 2 menunjukkan hasil penilaian tertinggi didapatkan $45 \%$ dengan skor 2 (tidak paham) berkaitan dengan pertanyaan apa itu sistim imun.. Dari 4 pertanyaan yang diajukan secara keseluruhan tentang sisitim imun didapatkan nilai tertinggi 36,3\% dengan skor 2 (tidak paham). Data ini menunjukkan rata-rata tingkat pengetahuan masyarakat tentang sistim imun sangat rendah, sehingga perlu diberikan edukasi tentang sistim imun dan pentingnya menjaga imun tubuh

Tabel 2.

Pemahaman responden tentang sistim imun

\begin{tabular}{|c|c|c|c|c|c|c|c|c|c|c|}
\hline \multirow{2}{*}{ Pertanyaan } & \multicolumn{5}{|c|}{ Skor } & \multicolumn{5}{|c|}{ Persentase skor $(\%)$} \\
\hline & 1 & 2 & 3 & 4 & 5 & $\mathbf{1}$ & 2 & 3 & 4 & 5 \\
\hline Apakah paham tentang sistim imun & 2 & 9 & 6 & 2 & 5 & 10 & 45 & 30 & 10 & 5 \\
\hline Apakah ada usaha meningkatkan sistim imun & 3 & 7 & 6 & 7 & & 15 & 37 & 30 & 35 & \\
\hline $\begin{array}{l}\text { Apakah paham cara apa saja untuk } \\
\text { meningkatkan sistim imun }\end{array}$ & 1 & 5 & 7 & 7 & & 5 & 25 & 35 & 35 & \\
\hline $\begin{array}{l}\text { Apakah paham bahan yang perlu dikonsumsi } \\
\text { untuk meningkatkan sistm imun }\end{array}$ & & 8 & 5 & 6 & 5 & & 40 & 25 & 30 & 5 \\
\hline Total & 6 & 29 & 21 & 22 & 2 & 7.7 & 36.3 & 26.3 & 27.2 & 2.5 \\
\hline $\begin{array}{clc}\text { or: 1. Sangat tidak paham } & \text { 2. Tidak paham } & \text { 3. C } \\
\text { 1: Sangat tidak ada } & \text { 2. Tidak ada } & \text { 3. }\end{array}$ & $\mathrm{am}$ & $\begin{array}{l}\text { 4. } \mathrm{Pah} \\
\text { 4. Ad }\end{array}$ & & & & & & & & \\
\hline
\end{tabular}


Survey pengetahuan masyarakat berkaitan dengan tumbuhan obat tradisional ditunjukkan pada Tabel 3. Data menunjukkan $40 \%$ dari responden paham tentang tumbuhan obat, dan $40 \%$ bahkan sangat paham tentang tumbuhan obat tradisional. Namun data pada Tabel 3 menunjukkan rata-rata masyarakat tidak paham kalau tumbuhan obat yang cukup mudah didapatkan dapat digunakan intuk meningkatkan sistim imun. Khususnya tentang Tumbuhan pegagan (Cantela asiatica) dan meniran (Phyllanthus urinaria), rata-rata masyarakat tidak paham penggunaan tumbuhan obat tersebut.

Tabel 3.

Pemahaman responden tentang tanaman obat untuk meningkatkan sistim imun

\begin{tabular}{|c|c|c|c|c|c|c|c|c|c|c|}
\hline \multirow{2}{*}{ Pertanyaan } & \multicolumn{5}{|c|}{ Skor } & \multicolumn{5}{|c|}{ Persentase skor $(\%)$} \\
\hline & $\mathbf{1}$ & 2 & 4 & 4 & 5 & 1 & 2 & 3 & 4 & 5 \\
\hline Apakah paham tentang tumbuhan obat & 2 & 3 & 5 & 5 & 3 & 10 & 15 & 25 & 35 & 15 \\
\hline $\begin{array}{l}\text { Apakah ada menanam tumbuhan obat } \\
\text { dipekarangan rumah }\end{array}$ & 6 & 2 & 3 & 4 & 5 & 30 & 10 & 15 & 20 & 25 \\
\hline $\begin{array}{l}\text { Apakah anda paham tanaman obat yang dapat } \\
\text { meningkatkan sistim imun }\end{array}$ & 1 & 6 & 6 & 6 & 1 & 5 & 30 & 30 & 30 & 5 \\
\hline Apakah paham tentang tumbuhan meniran & 3 & 6 & 6 & 2 & 1 & 15 & 30 & 30 & 10 & 5 \\
\hline Apakah paham tentang tumbuhan pegagan & 4 & 4 & 6 & 4 & 2 & 20 & 20 & 30 & 20 & 10 \\
\hline Apakah paham tentang mengkudu & & 1 & 3 & 8 & 8 & & 5 & 15 & 40 & 40 \\
\hline Apakah paham tentang temulawak & & 2 & 3 & 7 & 8 & & 10 & 15 & 35 & 40 \\
\hline $\begin{array}{l}\text { Apakah paham tentang rempah dapur (kunyit, } \\
\text { jahe, lengkuas) }\end{array}$ & & & 4 & 8 & 8 & & & 20 & 40 & 40 \\
\hline $\begin{array}{l}\text { Apakah ada menggunakan tumbuhan obat untuk } \\
\text { meningkatkan sistim imun }\end{array}$ & 2 & 6 & 3 & 8 & 1 & 10 & 30 & 15 & 40 & 5 \\
\hline $\begin{array}{l}\text { Apakah ada menggunakan obat atau vitamin } \\
\text { dipasaran untuk meningkatkan sistim imun }\end{array}$ & 4 & 3 & 2 & 5 & 6 & 20 & 15 & 10 & 25 & 30 \\
\hline Total skor & 24 & 33 & 41 & 59 & 43 & 12 & 16.5 & 20.5 & 29.5 & 21.5 \\
\hline $\begin{array}{cll}\text { Ket Skor : 1. Sangat tidak paham } & \text { 2. Tidak paham } & \text { 3. Cuku } \\
\text { 1: Sangat tidak ada } & \text { 2. Tidak ada } & \text { 3. Cuku }\end{array}$ & & 4.7 & & 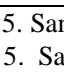 & $a_{1}$ & & & & & \\
\hline
\end{tabular}

Kegiatan Selanjutnya diberikan edukasi tentang sistim imun. Masyarakat diberikan penjelasan tentang sistim imun. Sistem daya tahan tubuh atau imunitas secara sederhana dapat dipahami sebagai sistem kerja tubuh untuk melawan penyakit. Sistem ini akan melindungi tubuh dari serangan organisme atau kuman yang dapat menyebabkan penyakit. (Adhi, 2020). sistem imunitas tubuh secara normal dapat bekerja sangat efisien dalam menghadapi ancaman musuh tersebut. Namun, saat sistem imunitas ini terkadang dalam kondisi lemah, sehingga tubuh jadi mudah terserang penyakit. Maka dari itu, agar tubuh kembali kebal terhadap penyakit, sistem imunitasnya harus terus dijaga dan ditingkatkan. Masyarakat juga diberikan edukasi cara meningkatkan sistim imun tubuh diantaranya yaitu dengan mengonsumsi suplemen kesehatan, termasuk jamu atau tanaman herbal. Terdapat sejumlah tanaman obat yang baik dikonsumsi untuk meningkatkan daya tahan tubuh, terlebih pada masa pandemi COVID-19 sekarang ini diantaranya kunyit, jahe, lengkuas, pegagan, mengkudu, temu lawak, pegagan dan meniran.

Kunyit adalah tanaman yang memiliki banyak manfaat kesehatan, termasuk meningkatkan kekebalan tubuh. Senyawa curcumin yang terkandung dalam kunyit dapat bersifat sebagai imunomodulator (meningkatkan 
mekanisme pertahanan tubuh) dan anti-inflamasi. Pada kasus Covid-19 sendiri, curcumin dalam kunyit mampu berikatan dengan reseptor protein SARS-CoV-2, yaitu melalui ikatan dengan domain protease (6Lu7) dan spike glikoprotein. Ikatan tersebut berpotensi dapat menghambat aktivitas Covid-19 dan menghambat perbanyakan virus. Selain itu, curcumin juga mampu menghambat pelepasan sitokin pro inflamasi (Widiyastuti, 2020). Dengan terhambatnya pengeluaran sitokin, maka tidak akan terjadi badai sitokin yang berdampak pada gangguan pernafasan. Selain terkandung dalam tanaman kunyit (Curcuma domestica), curcumin juga dapat ditemukan dalam tanaman temulawak (Curcuma xanthorhiza). Penggunaan curcumin sebagai senyawa tunggal tentu berbeda dengan penelitian penggunaan kunyit atau temulawak sebagai bahan herbal atau jamu. Temulawak, kunyit, dan meniran merupakan tanaman obat yang mampu meningkatkan kebugaran (Depkes, 2017). Selain itu Kusumadewi, (2020) melaporkan khasiat ekstrak meniran juga dapat meningkatkan kekebalan tubuh. Meniran mengandung senyawa phylantin dan hipophylantin yang mampu memodulasi sistem imun bawaan.

Masyarakat sangat mengenal kunyit namun tidak paham selama ini kalau kunyit juga dapat meningkatkan sistim imun. Sementara itu masyarakat rata-rata tidak kenal dengan tumbuhan pegagan dan meniran, dan tidak pernah memanfaatkan tubuhan ini.

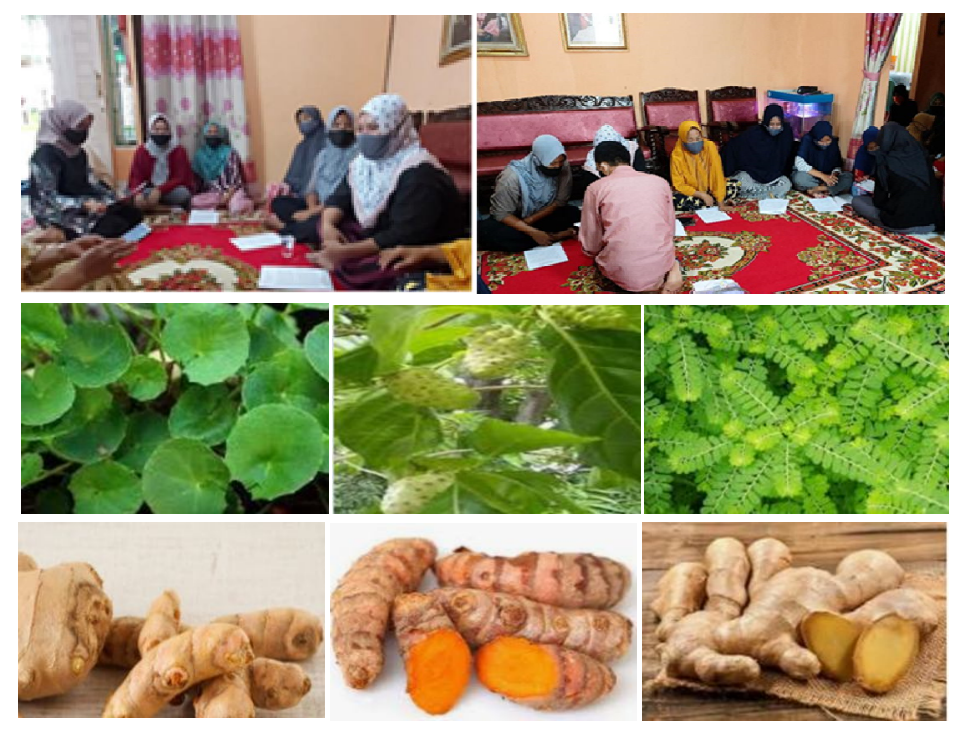

Gambar 1.

Pelaksana kegiatan pengabdian kepada masyarakat yang mengikut sertakan mahasiswa Fakultas Pertanian UHO (baris atas) dan jenis tanaman obat-obatan yang bermanfaat meningkatkan kekebalan tubuh seperti pegagan, mengkudu, dan meniran (baris tengah), temu lawak, kunyit, dan jahe (baris bawah).

Di samping itu jahe (Zingiber officinali) dan lengkuas juga dapat digunakan meningkatkan sistim imun. Jahe mengandung minyak atsiri dengan komponen utamanya adalah gingerol dan shogaol yang memiliki efek antiinflamasi dan antioksidan yang kuat (Pujilestari dan Lestari, 2009). Senyawa tersebut dapat membantu menurunkan risiko infeksi serta menghambat pertumbuhan berbagai jenis bakteri dan virus. Penelitian lain mengungkap kandungan senyawa kimia Zingiber officinale memiliki aktivitas antivirus terhadap human respiratory syncytial virus (HRSV), hepatitis C virus (HCV), dan Influenza (Kharisma et al., 2020) 
Lengkuas mampu meningkatkan imun tubuh yang terbukti kandungan senyawa glikosida kuersetin dalam lengkuas mampu meningkatkan antibodi. Lengkuas juga mengandung galangin. Galangin sendiri dapat menghambat inisiasi infeksi virus SARS-CoV-2 penyebab COVID-19. Lengkuas baik dikonsumsi untuk tujuan pencegahan atau preventif, bukan untuk upaya kuratif atau penyembuhan. Lengkuas dapat dijadikan sebagai tanaman herbal untuk mencegah masuknya agen penyakit ke dalam tubuh dengan memperkuat sistem kekebalan tubuh (Lestari dan Susanti, 2020).

Tumbuhan obat lain seperti buah mengkudu dan pegagan juga merupakan tumbuhan obat yang baik dikonsumsi untuk mendongkrak imun tubuh. Senyawa aktif yang terkandung dalam buah mengkudu yang berperan untuk meningkatkan daya tahan tubuh adalah skopoletin mengandung protein, polisakarida, skopoletin, asam askorbat, prokseronin dan prokseroninase (Sjabana dan Bahalwan, 2002). Skopoletin juga berperan memperlebar saluran pembuluh darah dan memperlancar peredaran darah. senyawa polisakarida dalam jus buah mengkudu mempunyai potensial sebagai profilaktik maupun terapetik sebagai imunomodulator terhadap system tumor sarcoma 180. (Furuzawa, et al., 2003).

Tumbuhan obat lainnya adalah pegagan (Centela asiatica) mengandung senyawa glikosida triterpenoid dan asiatikosidadapat mempercepat perbaikan sel-sel kulit dan meningkatkan daya tahan tubuh (Griana, 2019). Sifat immunomodulator dari ekstrak pegagan juga telah di uji secara invivo (Kumala dkk., 2004). Ada tujuh kelompok utama senyawa terkandung didalam Pegagan: saponin, triterpenoid pentasiklik, sterol, siskuiterpen, turunan eugenol, caffeoylquinic aciddan flavonoid.Triterpenoid pentasiklikmerupakan kandungan yang tertinggi, yang disebut juga sebagai centelloids, dimana kandungan terbanyak berupa saponin, asiatikosidaand madekasosida, and aglikon, asam asiatik dan asam madekasik (James, 2011).

Setelah dilakukan penyuluhan, selanjutnya dilakukan diskusi. Masyarakat mulai paham tentang pentingnya menjaga sisitim imun tubuh khususnya dimasa pandemi Covid -19 ini. Masyarakat mulai terbuka wawasannya untuk memanfaatkan tumbuhan obat tradisional yang mudah didapatkan untuk menjaga sistim imun. Diharapkan kelompok masyrakat ini dapat menyebarkan informasi dan pengetahuan yang dimilikinya pada masyarakat lain, dan menjadikan kegiatan ini sebagai usaha preventif melindungi diri dan keluarga dari bahaya COVID-19.

\section{KESIMPULAN DAN SARAN}

Kegiatan yang dilakukan telah menambah pengetahuan masyarakat berkaitan dengan sistim imun dan penggunaan tumbuhan obat yang dapat digunakan untuk meningkatkan sistim imun tubuh, sehingga masyarakat dapat menjaga diri dan keluarganya dari wabah pandemi COVID-19.

\section{Ucapan Terima Kasih}

Penulis mengucapkan terima kasih kepada Universitas Sriwijaya yang telah mendanai kegiatan ini melalui Dana Pengabdian Pada Masyarakat Skim Aplikasi IPTEK dan pengembangan budaya lokal Tahun 2020. 


\section{Daftar Pustaka}

Adhi, I. S., 2020. Tanaman Herbal untuk Meningkatkan Daya Tahan Tubuh https://health.kompas.com/read/2020/09/05/193200068/7tanaman-herbal-untuk meningkat kan daya tahan tubuh?page=all. Diakses 26 September 2020.

Depkes, 2017, Dalam saintifikasi jamu dan di Rumah Riset Jamu Hortus Medicus B2P2TOOT Tawangmangu, Kemenkes RI.

Flora, R., Hikayati, Purwanto, S., 2013. Pelatihan senan kaki pada penderita iabetes mellitus dalam upaya pencegahan komplikasi diabetes pada kaki (diabetes food). 1(1), 7-15.

Furuzawa, E., Hirazumi, A., Story, S., and Jensen, J., 2003, Antitumor potential of a polysaccharide-rich substance from the fruit juice of Morinda citrifolia (Noni) on sarcoma 180 ascites tumour in mice. Phytother Res., 17(10):1158-1164.

Griana, T.P. Potensi 2019, Tanaman Pegagan (Centella asiatica L. Urban) danWiduri (Calotropis gigantea L.) sebagai Imunomodulator. J. Food Pharm. Sci., 7(2),55-72

Hikayati, 2024, Penatalaksanaan non farmakologis terapi komplementer sebagai upaya untuk mengatasi dan mencegah komplikasi sebagai upaya untuk mengatasi dan mencegah komplikasi pada penderita hipertensi primer di kelurahan indralaya mulya kabupaten Ogan Ilir, Jurnal Pengabdian Sriwijaya, 2(2): 124-131.

James, J., and Dubery, I., 2011, Identification and Quantification of Triterpenoid Centelloids in Centella asiatica (L.) Urban by Densitometric TLC. JPC-Modern TlC, 24(1):82-87.

Kharisma, V. D, Ansori, A. N. M., and Nugraha, A. P. 2020. Computational study of ginger (Zingiber officinale) as inhibitor in human papilloma virus type 16 (HPV 16) infection. Biochem. Cell. Arch. 20(1): 3155-3159.

Kumala S, Dewi A.T., Nugroho, Y.A. 2004. Efek Imunostimulan Ekstrak Etanolik Herba Pegagan (Centella asiatica (L.) Urban) terhadap IgG Mencit Jantan. JIFI, 2(2);53-58.

Kusumadewi, P. 2020. Warta Hortus Med Ed.1, Balai Besar Penelitian dan Pengembangan Tanaman Obat dan Obat Tradisional (B2P2TOOT), Kemenkes RI.

Lestari F, Susanti I. Tumbuhan obat berpotensi imunomodulator di suku anak dalam bendar bengkulu. Jurnal Pendidikan Biologi, Vol. 5, No. 1: 64-72.

Pujilestari, T., dan Lestari, N. 2009. Analisis Senyawa kimia pada tiga jenis jahe dan penggunaannya untuk industri. Jurnal Riset Teknologi Idustri, 3(6): 31-38

Sjabana, D. dan Bahalwan, R.R., 2002, Seri referensi herbal: Mengkudu. Salemba Medika, Jakarta.

Widiastuti, Y. 2020. Warta Hortus Med. Ed.1, Balai Besar Penelitian dan Pengembangan Tanaman Obat dan Obat Tradisional (B2P2TOOT), Kemenkes RI. 